\title{
Indiangrass and caucasian bluestem responses to different nitrogen sources and rates in the Ozarks
}

\author{
JOHN J. BREJDA, JAMES R. BROWN, AND CALVIN L. HOENSHELL
}

Authors are graduate assistant, Department of Agronomy, 279 Plant Sciences, University of Nebraska, Lincoln 685830915, professor, School of Natural Resources, and former research specialist (retired), Department of Agronomy, University of Missouri, Columbia 65211.

\begin{abstract}
Alternatives to cool-season grasses are needed for summer forage production on droughty, infertile soils in the Ozarks. The objective of this research was to compare nitrogen $(N)$ sources and application rates for improving forage production, crude protein concentration, and apparent fertilizer $\mathbf{N}$ recovery by 'Rumsey' indiangrass [Sorghastrum nutans (L.) Nash] and caucasian bluestem [Bothriochloa caucasia (Trin.) C.E. Hubbard]. Pure stands of each species were treated with urea, $\mathrm{NH}_{4} \mathrm{NO}_{3}$, or $\left(\mathrm{NH}_{4}\right)_{2} \mathrm{SO}_{4}$ at $0,56,112$, and $168 \mathrm{~kg} \mathrm{~N} \mathrm{ha}{ }^{-1}$ from 1985-1987. In 1988 the (NH4) ${ }_{2} \mathrm{SO}_{4}$ treatment was discontinued and in 1990 the $\mathrm{N}$ rates were increased to $0,78,157$, and $235 \mathrm{~kg} \mathrm{~N}$ ha-1. Forage yields, crude protein concentrations or both were greater with $\mathrm{NH}_{4} \mathrm{NO}_{3}$ compared to urea in 3 out of 6 years for indiangrass and 4 out of 6 years for caucasian bluestem. Indiangrass forage yields increased with increasing $N$ rates up to $168 \mathrm{~kg} \mathrm{~N} \mathrm{ha}^{-1}$. Caucasian bluestem forage yields peaked at $101 \mathrm{~kg} \mathrm{~N} \mathrm{ha}^{-1}$ in $1985,132 \mathrm{~kg} \mathrm{~N} \mathrm{ha}^{-1}$ in $1986,122 \mathrm{~kg} \mathrm{~N} \mathrm{ha}^{-1}$ in $1987,129 \mathrm{~kg} \mathrm{~N} \mathrm{ha}^{-1}$ in 1989 , and $161 \mathrm{~kg} \mathrm{~N} \mathrm{ha}^{-1}$ in 1990 . Crude protein concentrations of both species increased linearly with $\mathrm{N}$ rates in most years. At the lowest $N$ rate $\left(56 \mathrm{~kg} \mathrm{~N} \mathrm{ha}^{-1}\right)$ caucasian bluestem was more efficient than indiangrass in apparent fertilizer $N$ recovery, but at greater $\mathbf{N}$ rates the 2 species were similar in fertilizer $\mathbf{N}$ recovery. Forage yield and crude protein concentration of both species responded similarly to $\left(\mathrm{NH}_{4}\right)_{2} \mathrm{SO}_{4}$ and $\mathrm{NH}_{4} \mathrm{NO}_{3}$.
\end{abstract}

Key Words: Sorghastrum nutans (L.) Nash, Bothriochloa caucasia (Trin.) C.E. Hubbard, urea, ammonium-nitrate, ammoniumsulfate, fertilizer $\mathbf{N}$ recovery.

Tall fescue (Festuca arundinacea Schreb.) and other cool-season grasses are the predominant pasture species in the Ozarks. However, Ozark soils are generally shallow, rocky, and low in available nitrogen $(N)$, phosphorus $(P)$, water holding capacity, and $\mathrm{pH}$. Low soil fertility and water holding capacity, combined with high summer temperatures and periodic drought severely reduce cool-season grass forage production during the summer months.

Published as Journal Article 11,968, Agricultural Experiment Station, University of Missouri. The research was conducted with financial support from the Missouri Department of Conservation.

Manuscript accepted 31 Jul. 1994.
Native warm-season grasses grow well in acid soils (Jung et al. 1988, Staley et al. 1991), are more efficient in the use of water (Stout et al. 1986), N (Brown 1978, Brown 1985, Staley et al. 1991), P (Wuenscher and Gerloff 1971, Morris et al. 1982), and maintain growth at higher temperatures (Black 1971) than coolseason grasses. Griffin et al. (1980) compared the quality of big bluestem (Andropogon gerardii Vitman) and switchgrass (Panicum virgatum L.) to tall fescue and concluded that warmseason grass dry matter intake and dry matter digestibility were equal to or superior to summer or fall harvested tall fescue.

Nitrogen fertilizer can increase forage production and quality in warm-season grasses (Perry and Baltensperger 1979, Hall et al. 1982). However, not all $N$ sources are equally efficient in increasing forage production and quality. Economic and environmental concerns require that the most efficient source and rate of $\mathrm{N}$ be evaluated before recommendations are made to livestock producers. Urea is more concentrated, less hazardous to store and transport, and generally cheaper than ammonium nitrate $\left(\mathrm{NH}_{4} \mathrm{NO}_{3}\right)$, but is considered to be an inferior source of $\mathrm{N}$ for use on pastures (Wilkinson and Langdale 1974). The presence of plant residues may increase ammonia $\left(\mathrm{NH}_{3}\right)$ volatilization losses (Hargrove 1988), reducing recovery of $\mathrm{N}$ applied as urea. However, Westerman et al. (1983) concluded that urea was an efficient source of $\mathrm{N}$ for bermudagrass (Cynodon dactylon $\mathrm{L}$.) growing on moderately acid soils in Oklahoma. The low $\mathrm{pH}$ of Ozark soils and the practice of burning warm-season grass residues in the spring prior to urea application could reduce $\mathrm{NH}_{3}$ volatilization losses (Jackson and Burton 1962), making urea an efficient source of $\mathrm{N}$ for warm-season grasses under these conditions.

Surface application of soluble sulfate salts may decrease exchangeable aluminum ( $\mathrm{Al}^{3+}$ ) through the formation of $\mathrm{Al}$ hydroxyl-sulfate minerals or precipitation of $\mathrm{Al}^{3+}$ as $\mathrm{Al}(\mathrm{OH})_{3}$ following the exchange of $\mathrm{SO}_{4}{ }^{2-}$ for the $\mathrm{OH}$ ligand on hydrous oxide surfaces (Mathews and Joost 1989). Sulfate $\left(\mathrm{SO}_{4}{ }^{2-}\right)$ salts could improve subsoil fertility and root penetration by reducing exchangeable $\mathrm{Al}^{3+}$ toxicity (Mathews and Joost 1989). This suggests that the use of ammonium sulfate $\left[\left(\mathrm{NH}_{4}\right)_{2} \mathrm{SO}_{4}\right]$ may be an efficient source of $\mathrm{N}$ for warm-season grasses on acid soils with high Al content.

Indiangrass [Sorghastrum nutans (L.) Nash] and caucasian bluestem [Bothriochloa caucasia (Trin.) C.E. Hubbard] grow later into the fall than other warm-season grasses (Waller et al. 
1985, Soil Conservation Service 1993) and could be used in the Ozark region to provide high quality forage during the summer months. However, there is no information on appropriate $\mathrm{N}$ sources and rates to use in management of these species in the Ozarks. The objective of this research was to identify the best $\mathrm{N}$ source and appropriate application rates for improving yield and protein content of indiangrass and caucasian bluestem grown for forage production in the Ozarks.

\section{Materials and Methods}

The research was conducted from 1985-1990 using established pure stands of 'Rumsey' indiangrass and caucasian bluestem at the University of Missouri Southwest Center, Mt. Vernon, Mo. The Hoberg silt loam (fine-loamy, siliceous, mesic Mollic Fragiudalf) soil at the study site is gently sloping (2-5\%) with a fragipan at a depth of $40-90 \mathrm{~cm}$. The fragipan limits root growth, produces a perched water table from December through March, but reduces soil water availability during periods without rain in the summer. The available water holding capacity in the top 40 $\mathrm{cm}$ is low, ranging from $4.1-6.4 \mathrm{~cm}$. Soil pH of the top $15 \mathrm{~cm}$ was 5.57 with an organic matter content of $34 \mathrm{mg} \mathrm{kg}^{-1}$. Precipitation was measured at the site with a rain gauge (Table 1).

Table 1. Growing season precipitation at the University of Missouri Southwest Center during April through September 1985-1991 and the 28-year average.

\begin{tabular}{|c|c|c|c|c|c|c|c|}
\hline \multirow[b]{2}{*}{ Month } & \multicolumn{6}{|c|}{ Year } & \multirow{2}{*}{$\begin{array}{l}28 \text {-year } \\
\text { average }\end{array}$} \\
\hline & 1985 & 1986 & 1987 & 1988 & 1989 & 1990 & \\
\hline & & & & (cm) & $-\ldots$ & $\ldots$ & $\cdots$ \\
\hline April & 7.4 & 10.8 & 3.2 & 8.2 & 0.8 & 7.3 & 10.3 \\
\hline May & 11.5 & 5.2 & 9.8 & 5.3 & 12.3 & 36.5 & 11.5 \\
\hline June & 19.7 & 12.6 & 7.1 & 12.6 & 12.0 & 12.0 & 13.0 \\
\hline July & 4.2 & 2.9 & 9.3 & 10.7 & 19.6 & 5.8 & 7.2 \\
\hline August & 23.0 & 10.9 & 14.3 & 18.2 & 9.5 & 7.8 & 10.7 \\
\hline September & 8.1 & 27.0 & 6.0 & 14.6 & 9.9 & 13.3 & 11.8 \\
\hline Total & 73.9 & 69.4 & 49.8 & 62.1 & 64.1 & 82.7 & 64.5 \\
\hline
\end{tabular}

Each stand was divided into 3 blocks of 12 plots $(3 \times 6 \mathrm{~m})$ and each block was treated with a factorial combination of urea, $\mathrm{NH}_{4} \mathrm{NO}_{3}$, or $\left(\mathrm{NH}_{4}\right)_{2} \mathrm{SO}_{4}$ at 4 rates equivalent to $0,56,112$, and $168 \mathrm{~kg} \mathrm{~N} \mathrm{ha}{ }^{-1}$. After 1987 the $\left(\mathrm{NH}_{4}\right)_{2} \mathrm{SO}_{4}$ treatment was discontinued and comparisons were limited to urea and $\mathrm{NH}_{4} \mathrm{NO}_{3}$ at the same rates. In 1990, the $\mathrm{N}$ rates were increased to $0,78,157$, and $235 \mathrm{~kg} \mathrm{~N} \mathrm{ha}^{-1}$. The stands were burned in April each year and the $\mathrm{N}$ treatments applied 4 weeks later in mid to late May. All plots received spring applications of $22 \mathrm{~kg} \mathrm{P} \mathrm{ha}^{-1}$ and $112 \mathrm{~kg} \mathrm{~K} \mathrm{ha}^{-1}$ in 1986 and 1987, and $33 \mathrm{~kg} \mathrm{P} \mathrm{ha}{ }^{-1}$ and $112 \mathrm{~kg} \mathrm{~K} \mathrm{ha}^{-1}$ in 1988-1990, to replace $P$ and $K$ removed in the forage harvests.

Forage was harvested from a $1 \times 2 \mathrm{~m}$ strip in the center of each plot at a $5 \mathrm{~cm}$ cutting height using a flail type harvester. Fresh forage weights were measured in the field and a subsample collected from each plot, dried at $65^{\circ} \mathrm{C}$ for 48 hours in a forced-air oven, and weighed to determine percentage dry matter. The dried subsamples were ground in a Wiley mill to pass a $1-\mathrm{mm}$ screen and analyzed for Kjeldahl-N (Bremner and Mulvaney 1982) and crude protein concentrations were estimated $(\mathrm{N} \times 6.25)$. Apparent fertilizer $\mathrm{N}$ recovery was calculated using the formula of Caswell and Godwin (1984). Indiangrass was harvested on 19 July 1985 , 26 June 1986, 25 June 1987, 16 August 1988, 4 August 1989, and 7 July 1990. In 1985-1987, caucasian bluestem was harvested on the same dates as indiangrass. In 1988-1990, an initial caucasian bluestem harvest was taken on 5 July 1988, 6 July 1989, and 9 July 1990 and regrowth was harvested on 16 August 1988, 20 September 1989, and 30 August 1990.

\section{Statistical Analysis}

Data were analyzed separately for each species and harvest using analysis of variance, and fertilizer sources were compared using preplanned orthogonal contrasts. Contrasts compared forage responses to urea versus the average of $\mathrm{NH}_{4} \mathrm{NO}_{3}$ and $\left(\mathrm{NH}_{4}\right)_{2} \mathrm{SO}_{4}$, and $\mathrm{NH}_{4} \mathrm{NO}_{3}$ versus $\left(\mathrm{NH}_{4}\right)_{2} \mathrm{SO}_{4}$. Plant responses to the different $\mathrm{N}$ rates were analyzed using orthogonal polynomials for significant linear and quadratic responses (Stcel and Torrie 1980). Year effects were treated as repeated measures in time and analyzed using a split-plot design described by Steel and Torrie (1980). Analysis over years was performed for the years 1985 through 1987 and 1988-1989. Data from 1990 were analyzed separately because different $\mathrm{N}$ rates were used. Treatment differences were considered significant at the 0.05 probability level.

\section{Results}

\section{Indiangrass}

Forage Yields

Indiangrass forage yields varied significantly with years, reflecting yearly differences in growing season precipitation (Table 1) and harvest dates. Year by $N$ source and year by $N$ rate interactions were not significant in 1985-1987 or 1988-1989. Indiangrass forage yields did not differ with $\mathrm{N}$ source in $1985-1987$, and the $N$ source by rate interaction was not significant for these 3 years. Within years, indiangrass forage yields increased linearly with $N$ rate in 1985 , but increased curvilinearly with $\mathrm{N}$ rate in 1986 and 1987 (Fig. 1). May and June precipitation was below normal in both 1986 and 1987 (Table 1), which may have limited forage production at the higher $\mathrm{N}$ rates, producing the curvilinear yield response.

Indiangrass forage yields in 1988 (Fig. 1) and 1989 (Fig. 2) were the greatest for the 6 year period of study. In 1988 and 1989, indiangrass was harvested in August and growing season precipitation prior to harvest was near the long term average (Table 1). Good growing season precipitation and a delay in the forage harvest combined to produce high forage yields. In 1988, indiangrass forage yields did not differ between $\mathrm{NH}_{4} \mathrm{NO}_{3}$ and urea, and yields increased curvilinearly with $\mathrm{N}$ rate. In 1989 and 1990, indiangrass forage yields increased linearly with increasing rate of urea, but increased curvilinearly with increasing rate of $\mathrm{NH}_{4} \mathrm{NO}_{3}$ (Fig. 2). At intermediate $\mathrm{N}$ rates, indiangrass produced $1,300-1,550 \mathrm{~kg} \mathrm{ha}{ }^{-1}$ more forage when treated with $\mathrm{NH}_{4} \mathrm{NO}_{3}$ compared to urea, but produced similar yields at the highest rate of both $\mathrm{N}$ sources.

\section{Crude Protein Concentrations}

Indiangrass crude protein concentrations increased linearly with $N$ rate in 1985 and 1986, but increased curvilinearly with $N$ rate in 1987. In addition, the magnitude of the linear increase in 


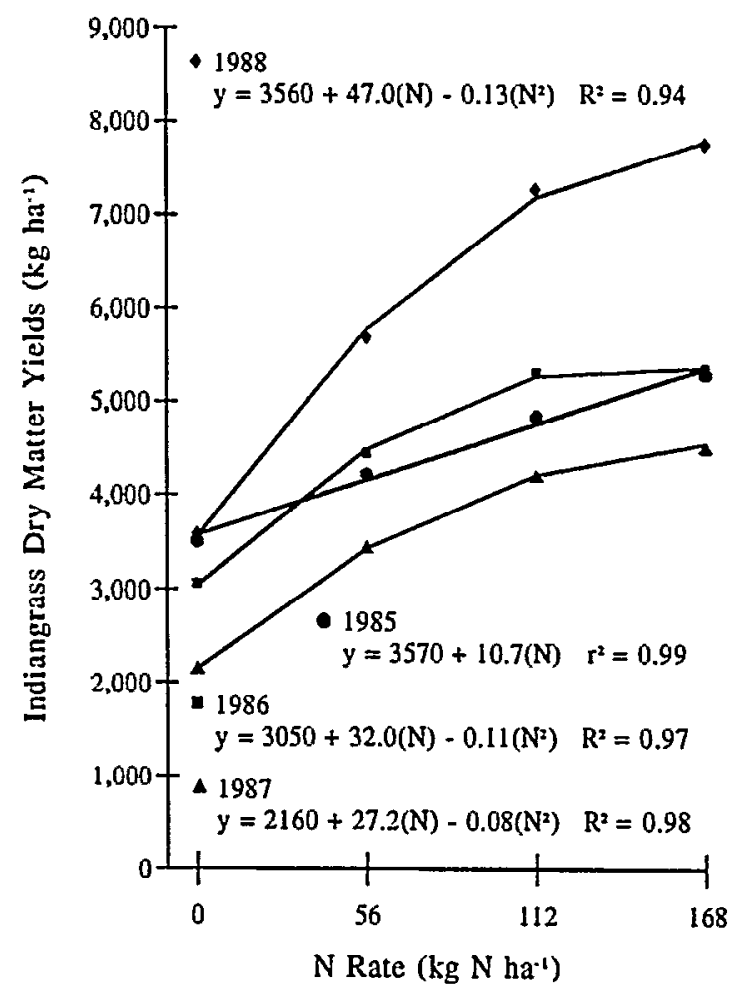

Fig. 1. Indiangrass forage dry matter yields averaged over $\mathrm{N}$ sources (urea, $\mathrm{NH}_{4} \mathrm{NO}_{3}$, and $\left(\mathrm{NH}_{4}\right)_{2} \mathrm{SO}_{4}$ ) at 4 application rates from 19851988.

crude protein concentrations with $\mathrm{N}$ rate was greater in 1986 than in 1985, causing an $\mathrm{N}$ rate by year interaction (Fig. 3). In 1985, $\mathrm{NH}_{4} \mathrm{NO}_{3}$ and $\left(\mathrm{NH}_{4}\right)_{2} \mathrm{SO}_{4}$ produced an additional $0.98-1.59 \%$

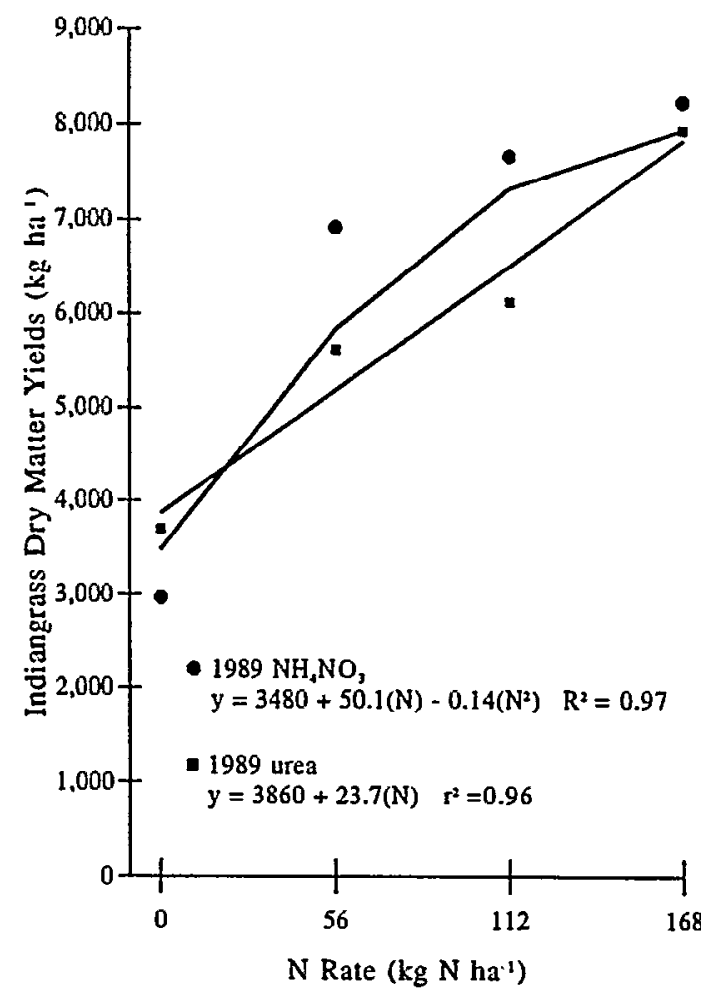

(absolute) crude protein compared to urea at all $\mathrm{N}$ rates (Fig. 3). In 1986 and 1987, indiangrass crude protein concentrations did not differ significantly between the $3 \mathrm{~N}$ sources (Fig. 3). In 1988 and 1990, indiangrass cnide protein concentrations increased linearly with $\mathrm{N}$ rate, but the increase was greater for $\mathrm{NH}_{4} \mathrm{NO}_{3}$ than urea, causing a significant $\mathrm{N}$ source by rate interaction (Fig. 4). At low $\mathrm{N}$ rates (56 kg N ha-1 in 1988 and $78 \mathrm{~kg} \mathrm{ha}^{-1}$ in 1990), indiangrass crude protein concentrations were similar for $\mathrm{NH}_{4} \mathrm{NO}_{3}$ and urea. However, at rates greater than $112 \mathrm{~kg} \mathrm{~N} \mathrm{ha}^{-1}$, crude protein concentrations were $0.38-1.50 \%$ greater with $\mathrm{NH}_{4} \mathrm{NO}_{3}$ than urea.

In 1989, indiangrass crude protein concentrations were low at all $\mathrm{N}$ rates, with no difference between $\mathrm{NH}_{4} \mathrm{NO}_{3}$ and urea (Fig. 4). In 1989, abundant May, June, and July precipitation (Table 1) produced the greatest indiangrass forage yields for the 6 year period. The abundant growth may have diluted tissue $\mathrm{N}$ levels and high precipitation amounts may have leached fertilizer $\mathrm{N}$ from the soil, reducing $N$ uptake.

\section{Apparent Fertilizer N Recovery}

Apparent fertilizer $N$ recovery by indiangrass varied significantly with years (Table 2). However, the year by $\mathrm{N}$ source and year by $\mathrm{N}$ rate interactions were not significant for apparent fertilizer $\mathrm{N}$ recovery. In 1985, 4-18\% more fertilizer $\mathrm{N}$ was recovered by indiangrass fertilized with $\mathrm{NH}_{4} \mathrm{NO}_{3}$ and $\left(\mathrm{NH}_{4}\right)_{2} \mathrm{SO}_{4}$ compared to urea. Apparent fertilizer $\mathrm{N}$ recovery by indiangrass was not significantly different between the $2 \mathrm{NH}_{4}{ }^{+}$sources. In 1986, apparent fertilizer $\mathrm{N}$ recovery by indiangrass was not significantly different between the $\mathrm{N}$ sources or rates. In 1987, apparent fertilizer $\mathrm{N}$ recovery decreased linearly with increasing $\mathrm{N}$ rate, but $\mathrm{N}$ recovery did not differ with $\mathrm{N}$ source. In 1988-1990, indiangrass recovered 4.3-23.9\% more fertilizer $\mathrm{N}$ from $\mathrm{NH}_{4} \mathrm{NO}_{3}$ than from urea. In addition, in 1990 apparent fertilizer $\mathrm{N}$ recovery decreased

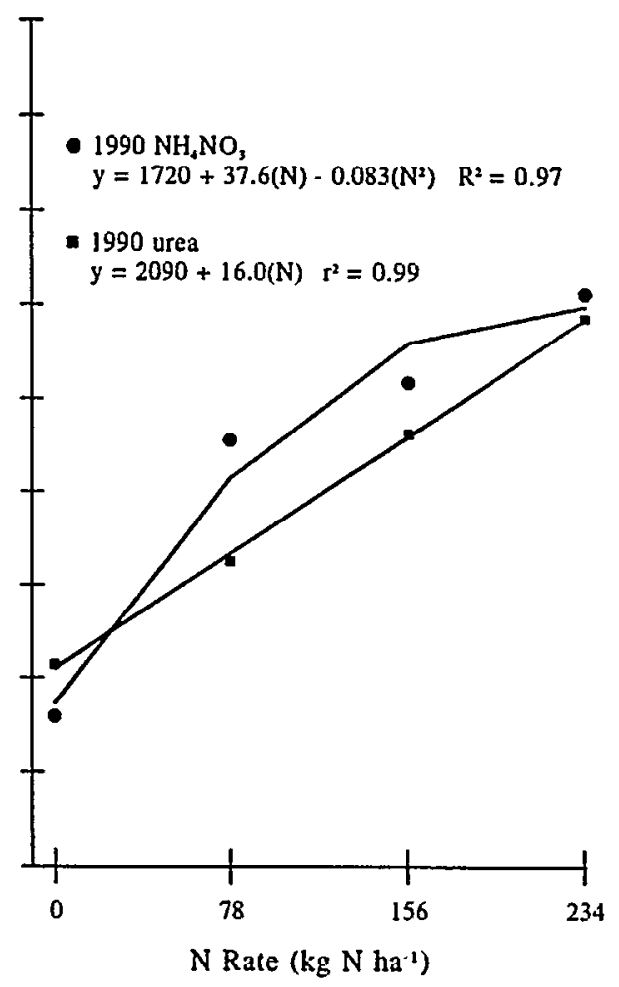

Fig. 2. Indiangrass forage dry matter yields treated with urea or $\mathrm{NH}_{4} \mathrm{NO}_{3}$ at 4 application rates in 1989 and 1990. 
Table 2. Nitrogen uptake in unfertilized control plots and apparent fertilizer $N$ recovery by indiangrass during 1985-1990 when $N$ was applied as urea (U), $\mathrm{NH}_{4} \mathrm{NO}_{3}(\mathrm{AN})$, or $\left(\mathrm{NH}_{4}\right)_{2} \mathrm{SO}_{4}(\mathrm{AS})$.

\begin{tabular}{llllllll}
\hline \multirow{2}{*}{ N rate } & \multicolumn{5}{c}{ Year } & $\begin{array}{c}\text { 6-year } \\
\text { aver } \\
\text { age }\end{array}$ \\
\cline { 2 - 8 } & 1985 & 1986 & 1987 & 1988 & 1989 & $1990^{2}$ &
\end{tabular}

N uptake in unfertilized control plots

$31 \quad 30 \quad 20 \quad 29 \quad 20 \quad 17 \quad(\mathrm{~kg} \mathrm{ha})$

Apparent fertilizer $\mathrm{N}$ recovery

\begin{tabular}{lccccccc} 
Urea & & & & & & & \\
56 & 19 & 42 & 43 & 24 & 29 & 30 & 31 \\
112 & 19 & 49 & 45 & 42 & 29 & 28 & 35 \\
168 & 24 & 42 & 39 & 32 & 31 & 33 & 33 \\
\multicolumn{1}{l}{ Ammonium nitrate } & & & & & & \\
56 & 37 & 51 & 48 & 48 & 39 & 53 & 46 \\
112 & 35 & 51 & 41 & 50 & 40 & 41 & 43 \\
168 & 27 & 38 & 36 & 41 & 35 & 37 & 36 \\
\multicolumn{1}{l}{ Ammonium sulfate } & & & & & & \\
56 & 38 & 47 & & & & 50 & 45 \\
112 & 36 & 51 & & & & 43 & 43 \\
168 & 9 & 40 & & & & 34 & 34
\end{tabular}

Analysis of variance

\begin{tabular}{lllllll} 
N source & 0.01 & NS & NS & 0.05 & 0.05 & 0.01 \\
AN + AS & 0.01 & NS & NS & - & - & - \\
vs U & & & & & & \\
AN vs AS & NS & NS & NS & - & - & - \\
N rate & NS & NS & 0.05 & NS & NS & NS \\
N linear & NS & NS & 0.05 & NS & NS & NS \\
N qua- & NS & NS & NS & NS & NS & NS \\
dratic & & & & & & \\
N source NS & NS & NS & NS & NS & 0.05 & \\
×rate & & & & & & \\
\hline
\end{tabular}

'N rates in 1990 were 78,157 , and $235 \mathrm{~kg} \mathrm{~N} \mathrm{ha}^{-1}$.

with increasing rate of $\mathrm{NH}_{4} \mathrm{NO}_{3}$, but changed little with increasing rate of urea (Table 2), resulting in a significant $\mathrm{N}$ source by rate interaction. Other than the linear decrease in apparent fertilizer $N$ recovery with increasing $N$ rate in 1987 and the $N$ source by rate interaction in 1990, $N$ rate had little effect on apparent fertilizer $N$ recovery.

Fertilizer $\mathrm{N}$ recovery by indiangrass in our study was lower than the values of 52-66\% reported by McMurphy et al. (1975) in Oklahoma. However, apparent fertilizer $\mathrm{N}$ recovery was 2-fold greater than values calculated from data by Jung et al. (1990) for indiangrass treated with $75 \mathrm{~kg} \mathrm{~N}^{-1}$ in Pennsylvania. Nitrogen uptake by indiangrass on control plots in our study averaged 24.5 $\mathrm{kg} \mathrm{ha}^{-1}$ and varied considerably with years (Table 2), but was lower than the $40 \mathrm{~kg} \mathrm{~N}$ ha-1 reported by Jung et al. (1990) for indiangrass harvested at head emergence in Pennsylvania. Soils at our site and the Pennsylvania site were similar, but the longer growing season in southern Missouri compared to Pennsylvania may in part explain the differences in apparent fertilizer $\mathrm{N}$ recovery.

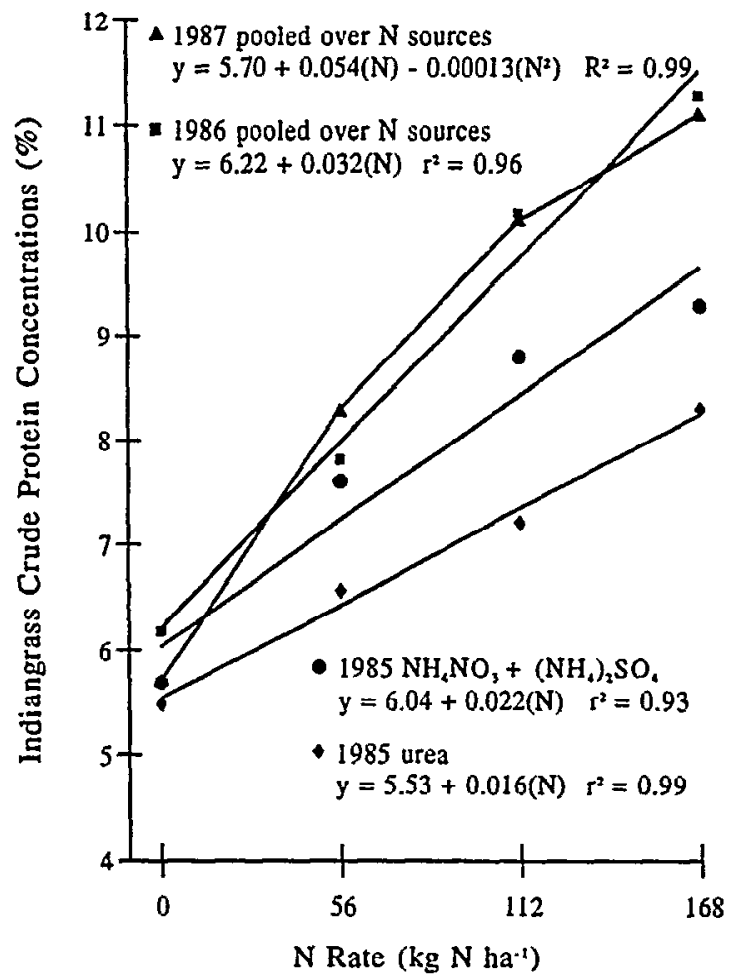

Fig. 3. Crude protein concentrations of indiangrass treated with urea, $\mathrm{NH}_{4} \mathrm{NO}_{3}$ or $\left(\mathrm{NH}_{4}\right)_{2} \mathrm{SO}_{4}$ at 4 application rates in 1985, and averaged over $\mathrm{N}$ sources in 1986 and 1987.

\section{Caucasian Bluestem \\ Forage Yields}

Caucasian bluestem yields varied significantly with years in 1985-1987 and 1988-89, reflecting differences in growing season precipitation (Table 1) and harvest dates. In addition, in 1988-1989 the year by $N$ rate interaction was significant for both the first and regrowth harvest forage yields. The year by $\mathrm{N}$ source interaction was not significant in 1985-1987 or for either harvest in 1988-1989.

In 1985 , caucasian bluestem forage yields were significantly greater with $\mathrm{NH}_{4} \mathrm{NO}_{3}$ and $\left(\mathrm{NH}_{4}\right)_{2} \mathrm{SO}_{4}$ than urea at all $\mathrm{N}$ rates (Table 3). Caucasian bluestem forage yields increased linearly with increasing rates of $\left(\mathrm{NH}_{4}\right)_{2} \mathrm{SO}_{4}$, but increased curvilinearly with increasing rates of $\mathrm{NH}_{4} \mathrm{NO}_{3}$ and urea, with a $1,000 \mathrm{~kg} \mathrm{ha}^{-1}$ yield decrease at the highest $\mathrm{N}$ rate. Campbell et al. (1977) reported decreased dry matter accumulation by spring wheat (Triticum aestivum L.) with rates of $\mathrm{N}$ exceeding $61.5 \mathrm{~kg} \mathrm{~N}$ hat. They concluded that greater rates of $\mathrm{N}$ stimulated excessive growth early in the spring which increased transpiration and more rapid use of soil moisture. As a result, plants suffered greater levels of moisture stress during extended periods between rains, depressing dry matter production.

In 1985 , caucasian bluestem forage yields peaked at $5,450 \mathrm{~kg}$ $\mathrm{ha}^{-1}$ at $101 \mathrm{~kg} \mathrm{~N} \mathrm{ha}^{-1}$ with $\mathrm{NH}_{4} \mathrm{NO}_{3}$ and $4,720 \mathrm{~kg} \mathrm{ha}^{-1}$ at the same $\mathrm{N}$ rate with urea. In 1986 and 1987, cancasian bluestem forage yields increased curvilinearly with $\mathrm{N}$ rate, with no difference between the $\mathrm{N}$ sources both years (Table 3 ). A maximum yield of $5,590 \mathrm{~kg}$ forage ha- was reached at $132 \mathrm{~kg} \mathrm{~N} \mathrm{ha}^{-1}$ in 1986 and a yield peak of $5,690 \mathrm{~kg}$ forage ha.-1 was attained at $122 \mathrm{~kg} \mathrm{~N} \mathrm{ha}^{-1}$ in 
Table 3. Forage dry matter yields and crude protein concentrations of caucasian bluestem treated with $\mathrm{NH}_{4} \mathrm{NO}_{3}(\mathrm{AN}),\left(\mathrm{NH}_{4}\right)_{2} \mathrm{SO}_{4}(\mathrm{AS})$ or urea (U) at 4 rates.

\begin{tabular}{|c|c|c|c|c|c|c|c|c|c|c|}
\hline \multirow[b]{2}{*}{ N rate } & \multicolumn{3}{|c|}{1985} & \multicolumn{3}{|c|}{1986} & \multicolumn{4}{|c|}{1987} \\
\hline & $\mathrm{NH}_{4} \mathrm{NO}_{3}$ & $\left(\mathrm{NH}_{4}\right)_{2} \mathrm{SO}_{4}$ & urea & $\mathrm{NH}_{4} \mathrm{NO}_{3}$ & $\left(\mathrm{NH}_{4}\right)_{2} \mathrm{SO}_{4}$ & urea & & $\mathrm{NH}_{4} \mathrm{NO}_{3}$ & $\left(\mathrm{NH}_{4}\right)_{2} \mathrm{SO}_{4}$ & urea \\
\hline \multicolumn{11}{|l|}{ Dry matter yields } \\
\hline \multicolumn{11}{|c|}{ - } \\
\hline 56 & 5000 & 4450 & 4200 & 5170 & 4890 & 4660 & & 5880 & 5570 & 5530 \\
\hline 112 & 5280 & 4830 & 4730 & 5760 & 4940 & 5270 & & 5790 & 5870 & 5470 \\
\hline 168 & 4250 & 5940 & 3690 & 5610 & 5530 & 5240 & & 5810 & 6230 & 5410 \\
\hline & & -- & . & 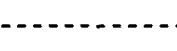 & $(\mathrm{P}>\mathrm{F})-$ & . . . . & & $\ldots$ & -- & \\
\hline N source & & 0.05 & & & NS & & & & NS & \\
\hline$A N+A S$ vs $\mathrm{U}$ & & 0.05 & & & NS & & & & NS & \\
\hline AN vs AS & & NS & & & NS & & & & NS & \\
\hline N rate & & 0.01 & & & 0.01 & & & & 0.01 & \\
\hline $\mathrm{N}$ linear & & 0.01 & & & 0.01 & & & & 0.01 & \\
\hline 0 & 5.5 & 5.7 & 5.7 & 5.7 & 5.3 & 5.2 & 5.0 & & & \\
\hline 56 & 6.3 & 6.0 & 5.3 & 8.0 & 8.0 & 7.1 & & 7.3 & 7.8 & 7.1 \\
\hline 112 & 7.6 & 8.4 & 7.1 & 9.9 & 10.3 & 9.0 & & 9.0 & 8.8 & 8.1 \\
\hline 168 & 8.8 & 8.3 & 8.8 & 12.8 & 11.8 & 10.3 & & 8.5 & 10.0 & 9.1 \\
\hline \multicolumn{11}{|c|}{ Analysis of variance } \\
\hline & & $-\cdots$ & . & 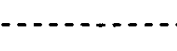 & $(P>F)---$ & - & 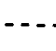 & - & -- & \\
\hline N source & & & & & NS & 0.01 & NS & & & \\
\hline$A N+A S$ vs $U$ & & NS & & & 0.01 & & & & NS & \\
\hline AN vs AS & & NS & & & NS & & & & NS & \\
\hline N rate & & 0.01 & & & 0.01 & & & & 0.01 & \\
\hline $\mathrm{N}$ linear & & 0.01 & & & 0.01 & & & & 0.01 & \\
\hline
\end{tabular}

1987.

In 1988, caucasian bluestem forage yields from the first harvest increased linearly with $\mathrm{N}$ rate, and did not differ significantly between $\mathrm{NH}_{4} \mathrm{NO}_{3}$ and urea. However, with the regrowth forage harvest caucasian bluestem forage yields increased curvilinearly with $\mathrm{N}$ rate, and the magnitude of the increase was greater for $\mathrm{NH}_{4} \mathrm{NO}_{3}$ than urea at intermediate $\mathrm{N}$ rates, causing an $\mathrm{N}$ source by rate interaction (Table 4). Caucasian bluestem forage yields from the regrowth harvest were 2,450 to $2,600 \mathrm{~kg} \mathrm{ha}^{-1}$ greater than forage yields from the first harvest. In 1988, April precipitation was $2.1 \mathrm{~cm}$ below normal, and May precipitation was less than half of normal (Table 1), reducing first harvest yields. In contrast, July precipitation was $3.5 \mathrm{~cm}$ and August precipitation $7.5 \mathrm{~cm}$ above normal (Table 1), stimulating high regrowth forage yields (Table 4).

In 1989, May and June precipitation was near normal, and caucasian bluestem forage yields were the greatest of the 6 year period. First harvest forage yields increased curvilinearly with $\mathrm{N}$ rate, but did not differ significantly between $\mathrm{NH}_{4} \mathrm{NO}_{3}$ and urea. $\mathrm{A}$ maximum forage yield of $7,550 \mathrm{~kg} \mathrm{ha}^{-1}$ was attained with $129 \mathrm{~kg}$ $\mathrm{N} \mathrm{ha}{ }^{-1}$. In 1989, July precipitation was $12.4 \mathrm{~cm}$ above normal, delaying the regrowth harvest until 20 September, and resulting in the greatest caucasian bluestem regrowth yields for the 3 year period. Regrowth forage yields increased linearly with $\mathrm{N}$ rate, with no difference between $\mathrm{NH}_{4} \mathrm{NO}_{3}$ and urea.

In 1990, first harvest and regrowth forage yields were low, with no significant difference between $\mathrm{NH}_{4} \mathrm{NO}_{3}$ and urea (Table 4). First harvest yields increased curvilinearly with $\mathrm{N}$ rate, in which forage yields peaked at 3,000 kg ha'-1 with $161 \mathrm{~kg} \mathrm{~N} \mathrm{ha}^{-1}$. Cool spring temperatures and excessive precipitation in 1990 may have reduced first harvest forage yields. The site received $36.5 \mathrm{~cm}$ precipitation (25 cm above normal) in May 1990 (Table 1). Inhibition of percolation by the fragipan caused saturated soil conditions which persisted for an extended period of time. Caucasian bluestem does not tolerate saturated soils (Soil Conservation Service 1993).

Caucasian bluestem regrowth yields were also low in 1990 . This may reflect slow recovery from the saturated soil conditions in the spring, or below normal July and August precipitation (Table 1). Regrowth forage yields increased linearly with $\mathrm{N}$ rate, with no difference between $\mathrm{NH}_{4} \mathrm{NO}_{3}$ and urea.

\section{Crude Protein Concentrations}

In 1985-1987, caucasian bluestem crude protein concentrations increased linearly with $\mathrm{N}$ rate in 1985 and 1986, but increased curvilinearly with $\mathrm{N}$ rate in 1987. In addition, the magnitude of the linear increase in caucasian bluestem crude protein concentrations was greater in 1986 than in 1985, causing a significant year 

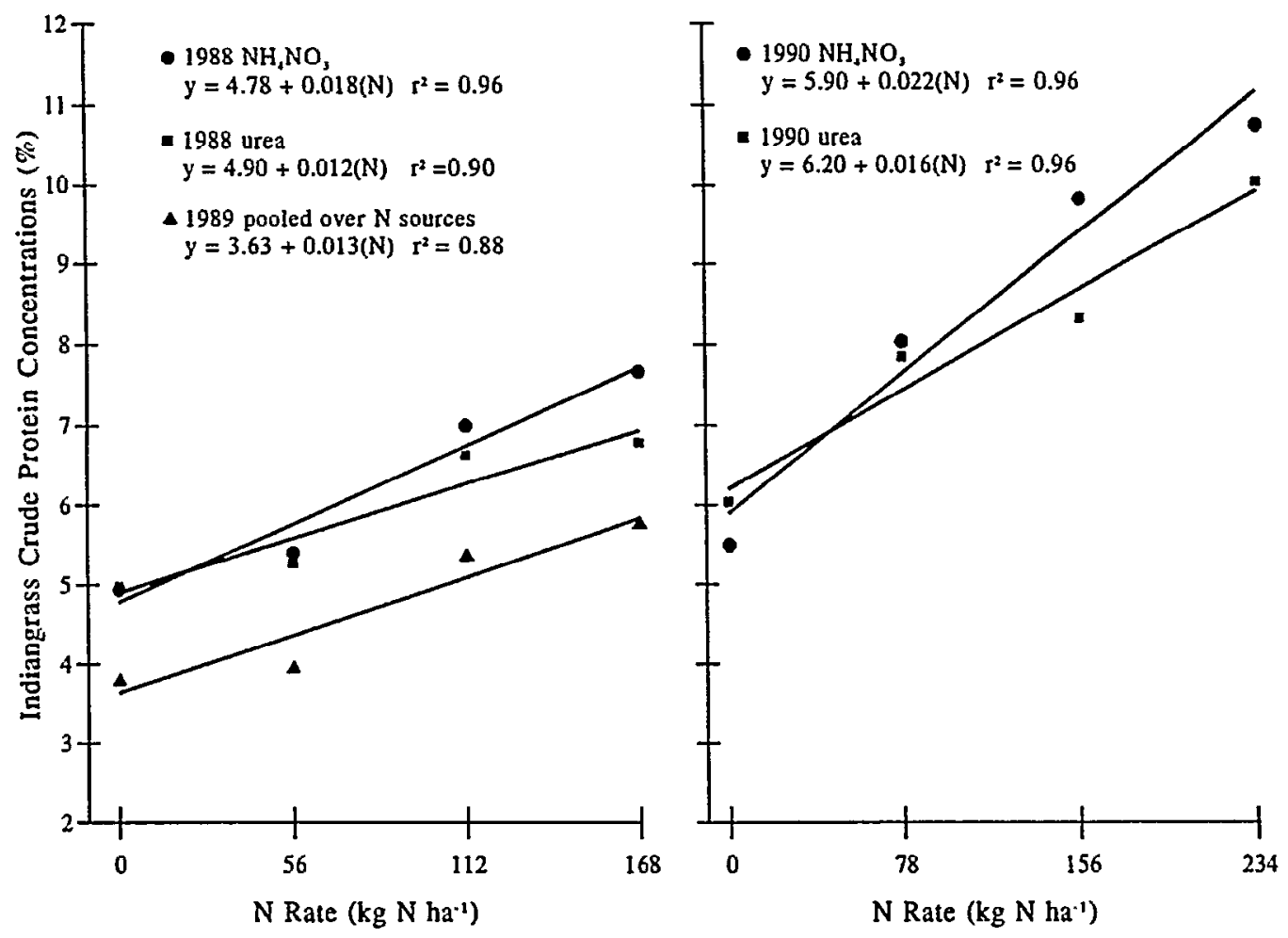

Fig. 4. Indiangrass crude protein concentrations treated with urea or $\mathrm{NH}_{4} \mathrm{NO}_{3}$ at 4 application rates in 1988-1990.

by $\mathrm{N}$ rate interaction. The year by $\mathrm{N}$ source interaction was not significant.

In 1985, caucasian bluestem crude protein concentrations did not differ significantly between the $3 \mathrm{~N}$ sources (Table 3 ). In 1986, caucasian bluestem crude protein concentrations increased linearly with $\mathrm{N}$ rate, and the magnitude of the increase was greater with $\mathrm{NH}_{4} \mathrm{NO}_{3}$ and $\left(\mathrm{NH}_{4}\right)_{2} \mathrm{SO}_{4}$ than urea, causing an $\mathrm{N}$ source by rate interaction (Table 3). There was no difference between the $2 \mathrm{NH}_{4}{ }^{+}$sources. In 1987, caucasian bluestem crude protein concentrations increased curvilinearly with $\mathrm{N}$ rate, and did not differ significantly between the $3 \mathrm{~N}$ sources (Table 3 ).

In 1988, caucasian bluestem crude protein concentrations from the first harvest increased linearly with $\mathrm{N}$ rate, and were greater with $\mathrm{NH}_{4} \mathrm{NO}_{3}$ than urea. However, with the regrowth harvest in 1988 , caucasian bluestem crude protein concentrations increased curvilinearly with $\mathrm{N}$ rate, and the increase was greater with $\mathrm{NH}_{4} \mathrm{NO}_{3}$ than urea, causing an $\mathrm{N}$ source by rate interaction (Table 4). This suggests that with the regrowth harvest in 1988, $\mathrm{NH}_{4} \mathrm{NO}_{3}$ provided a greater residual $\mathrm{N}$ response than urea.

Caucasian bluestem crude protein concentrations for the first and regrowth harvests in 1989 were the lowest of the 6 year period. Crude protein concentrations did not differ significantly between $\mathrm{NH}_{4} \mathrm{NO}_{3}$ and urea for either harvest. Caucasian bluestem crude protein concentrations increased linearly with increasing $\mathrm{N}$ rate for the first harvest, but increased curvilinearly with the regrowth harvest (Table 4). The abundant precipitation in 1989 stimulated the greatest caucasian bluestem forage yields for the 6 year period, which may have diluted crude protein concentrations and leached fertilizer $\mathrm{N}$ from the soil.

In 1990, caucasian bluestem crude protein concentrations from the first harvest increased linearly with $\mathrm{N}$ rate, and were signifi- cantly greater for $\mathrm{NH}_{4} \mathrm{NO}_{3}$ than urea (Table 4). Caucasian bluestem crude protein concentrations for the 1990 regrowth harvest increased linearly with $\mathrm{N}$ rate, and the magnitude of the increase was greater for $\mathrm{NH}_{4} \mathrm{NO}_{3}$ than urea, causing an $\mathrm{N}$ source by rate interaction.

\section{Apparent Fertilizer N Recovery}

Nitrogen uptake by caucasian bluestem in untreated control plots varied from a high of $29 \mathrm{~kg} \mathrm{~N} \mathrm{ha}{ }^{-1}$ in 1987 to a low of $11 \mathrm{~kg}$ $\mathrm{N} \mathrm{ha}^{-1}$ in 1990 (Table 5). These values were lower than an average value of $34.5 \mathrm{~kg} \mathrm{~N}^{-1}{ }^{-1}$ reported for unfertilized caucasian bluestem growing on droughty soils in Pennsylvania (Jung et al. 1990), but greater than an average value of $7 \mathrm{~kg} \mathrm{ha}^{-1}$ reported for old world bluestem (Bothriochloa ischaemum L.) in western Oklahoma (Berg 1990). However, in western Oklahoma, old world bluestem forage yields averaged only $800 \mathrm{~kg} \mathrm{ha}^{-1}$ without $\mathrm{N}$ fertilization (Berg 1990) compared to $2,730 \mathrm{~kg} \mathrm{ha}^{-1}$ for caucasian bluestem in this study.

Apparent fertilizer $\mathrm{N}$ recovery by caucasian bluestem during 1985 through 1987 was significantly greater with $\mathrm{NH}_{4} \mathrm{NO}_{3}$ and $\left(\mathrm{NH}_{4}\right)_{2} \mathrm{SO}_{4}$ than urea, but did not differ significantly between the $2 \mathrm{NH}_{4}^{+}$sources (Table 5). In 1985, apparent fertilizer $\mathrm{N}$ recovery declined linearly with increasing rate of $\left(\mathrm{NH}_{4}\right)_{2} \mathrm{SO}_{4}$, but showed no consistent change with increasing rates of $\mathrm{NH}_{4} \mathrm{NO}_{3}$ and urea, causing an $\mathrm{N}$ source by rate interaction (Table 5). In 1986 and 1987 , apparent fertilizer $N$ recovery declined linearly with increasing $\mathrm{N}$ rate, with no significant difference between the $3 \mathrm{~N}$ sources.

In 1988, apparent fertilizer $\mathrm{N}$ recovery by caucasian bluestem did not differ significantly between $\mathrm{N}$ sources or rates (Table 5). In 1989, apparent fertilizer $N$ recovery by caucasian bluestem 
Table 4. Forage dry matter yields and crude protein concentrations of caucasian bluestem treated with $\mathrm{NH}_{4} \mathrm{NO}_{3}(\mathrm{AN})$ or urea $(\mathrm{U})$ at 4 rates.

\begin{tabular}{|c|c|c|c|c|c|c|c|c|c|c|c|c|}
\hline \multirow{2}{*}{ N rate } & \multicolumn{4}{|c|}{1988} & \multicolumn{4}{|c|}{1989} & \multicolumn{4}{|c|}{$1990^{1}$} \\
\hline & \multicolumn{2}{|c|}{ first } & \multicolumn{2}{|c|}{ regrowth } & \multicolumn{2}{|c|}{ first } & \multicolumn{2}{|c|}{ regrowth } & \multicolumn{2}{|c|}{ first } & \multicolumn{2}{|c|}{ regrowth } \\
\hline \multicolumn{13}{|l|}{ Dry matter yields } \\
\hline 0 & 490 & 690 & 2040 & 2370 & 1750 & 1870 & 1860 & 1620 & 400 & 460 & 730 & 880 \\
\hline 56 & 1320 & 1400 & 4010 & 3540 & 5570 & 6740 & 2290 & 2740 & 2060 & 2470 & 1200 & 930 \\
\hline 112 & 1560 & 1930 & 4510 & 3930 & 7100 & 6980 & 4220 & 4510 & 2780 & 3330 & 1460 & 1320 \\
\hline N source & \multicolumn{2}{|l|}{ NS } & \multicolumn{2}{|c|}{ NS } & \multicolumn{2}{|c|}{ NS } & \multicolumn{2}{|c|}{ NS } & \multicolumn{2}{|c|}{ NS } & & \\
\hline N rate & \multicolumn{2}{|l|}{0.01} & \multicolumn{2}{|c|}{0.01} & \multicolumn{2}{|c|}{0.01} & \multicolumn{2}{|c|}{0.01} & \multicolumn{2}{|c|}{0.01} & \multicolumn{2}{|c|}{0.01} \\
\hline$N$ linear & \multicolumn{2}{|l|}{0.01} & \multicolumn{2}{|c|}{0.01} & 0.01 & & \multicolumn{2}{|c|}{0.01} & \multicolumn{2}{|c|}{0.01} & \multicolumn{2}{|c|}{0.01} \\
\hline N quadratic & NS & & 0.0 & & 0.01 & & NS & & 0.0 & & & \\
\hline 0 & 9.0 & 8.1 & 4.4 & 4.6 & 4.5 & 4.3 & 3.7 & 3.7 & 7.7 & 6.3 & 4.3 & 4.5 \\
\hline 56 & 12.1 & 10.8 & 5.1 & 4.6 & 4.4 & 4.7 & 3.4 & 3.5 & 7.6 & 6.1 & 5.2 & 4.6 \\
\hline 112 & 14.8 & 11.4 & 5.6 & 5.8 & 6.0 & 6.8 & 3.5 & 3.6 & 9.9 & 8.2 & 7.2 & 5.3 \\
\hline 168 & 14.0 & 13.7 & 7.9 & 6.4 & 6.8 & 6.8 & 4.5 & 4.2 & 10.7 & 9.2 & 8.3 & 6.3 \\
\hline Analysis of varia & & & & & & & & & & & & \\
\hline N source & 0.05 & & 0.0 & & NS & & NS & & 0.0 & & & \\
\hline N rate & 0.01 & & 0.0 & & 0.01 & & 0.0 & & 0.0 & & & 1 \\
\hline $\mathbf{N}$ linear & 0.01 & & 0.0 & & 0.01 & & 0.0 & & 0.0 & & & \\
\hline N quadratic & NS & & 0.0 & & NS & & 0.0 & & NS & & & \\
\hline$N$ source $\times$ rate & NS & & 0.0 & & NS & & NS & & NS & & & \\
\hline
\end{tabular}

'N rates in 1990 were 78,157 and $235 \mathrm{~kg} \mathrm{~N}$ ha'.

decreased linearly with increasing rate of urea, but did not change significantly with increasing rates of $\mathrm{NH}_{4} \mathrm{NO}_{3}$, causing an $\mathrm{N}$ source by rate interaction (Table 5 ). Caucasian bluestem had greater apparent fertilizer $\mathrm{N}$ recovery when treated with urea compared to $\mathrm{NH}_{4} \mathrm{NO}_{3}$ only in 1989 (Table 5). This response was not observed with indiangrass. At the 56 and $112 \mathrm{~kg} \mathrm{~N}^{-1}$ rates in this study, apparent fertilizer $\mathrm{N}$ recovery was generally greater than values calculated from data by Jung et al (1990) for caucasian bluestem treated with $75 \mathrm{~kg} \mathrm{~N}^{-1}$ in Pennsylvania, and for old world bluestem treated with 35 and $70 \mathrm{~kg} \mathrm{~N} \mathrm{ha}^{-1}$ in western Oklahoma (Berg 1990).

At $56 \mathrm{~kg} \mathrm{~N} \mathrm{ha-1,} \mathrm{an} \mathrm{average} \mathrm{of} 13 \%$ more fertilizer $\mathrm{N}$ was recovered by caucasian bluestem than by indiangrass. However, at greater $\mathrm{N}$ rates, apparent fertilizer $\mathrm{N}$ recovery was similar for the 2 warm-season grasses. Greater apparent fertilizer $N$ recovery by caucasian bluestem was expected because caucasian bluestem was harvested twice in 1988 through 1990 , while indiangrass was harvested once. Differences in apparent fertilizer $\mathrm{N}$ recovery among warm-season grass species have been reported. For instance, weeping lovegrass [Eragrostis curvula (Schrad.) Ness] recovered significantly more fertilizer $\mathrm{N}$ than 'Kaw' big bluestem, 'Caddo' switchgrass or indiangrass in Oklahoma (McMurphy et al. 1975).

\section{Discussion}

All $3 \mathrm{~N}$ sources increased indiangrass and caucasian bluestem forage yields and crude protein concentrations on shallow, droughty soils of the Ozarks, but they were not equally effective. With indiangrass, urea was as effective as $\mathrm{NH}_{4} \mathrm{NO}_{3}$ in increasing both forage production and crude protein concentrations in 3 of 6 years (1986, 1987 and 1990). With caucasian bluestem, urea was as effective as $\mathrm{NH}_{4} \mathrm{NO}_{3}$ in increasing both forage production and protein concentrations only 2 of 6 years (1987 and 1989). Similar results were reported by Berg (1993) for old world bluestem in western Oklahoma. Forage yields were greater with $\mathrm{NH}_{4} \mathrm{NO}_{3}$ than urea 2 out of 4 years, but there was no difference between the $2 \mathrm{~N}$ sources the other 2 years. This suggests that despite the low soil $\mathrm{pH}$ and the practice of removing grass residues by burning in the spring, urea was less reliable as a $\mathrm{N}$ source than $\mathrm{NH}_{4} \mathrm{NO}_{3}$ at this site.

Because urea is more concentrated, less hazardous to store and transport, generally cheaper and more readily available than $\mathrm{NH}_{4} \mathrm{NO}_{3}$, it will continue to be widely used by producers. Therefore, other management techniques may be needed that will reduce $\mathrm{N}$ losses from urea and improve its effectiveness relative to $\mathrm{NH}_{4} \mathrm{NO}_{3}$ for increasing forage yields and crude protein concentrations.

Indiangrass and caucasian bluestem forage yield and crude pro- 
Table 5. Nitrogen uptake in unfertilized control plots and apparent fertilizer $N$ recovery by caucasian bluestem during 1985-1990 when $N$ was applied as urea (U), $\mathrm{NH}_{4} \mathrm{NO}_{3}(\mathrm{AN})$, or $\left(\mathrm{NH}_{4}\right)_{2} \mathrm{SO}_{4}$ (AS).

\begin{tabular}{llllllll}
\hline \multirow{2}{*}{ N rate } & \multicolumn{9}{c}{ Year } & & & \multicolumn{1}{c}{ 6-year } \\
\cline { 2 - 7 } & 1985 & 1986 & 1987 & 1988 & 1989 & $1990^{1}$ & average \\
\hline
\end{tabular}

$\mathrm{N}$ uptake in unfertilized control plots

$22 \quad 26 \quad 29 \quad 24 \quad 23 \quad 11 \quad 22$

Apparent Fertilizer N Recovery

$\begin{array}{cccccccc} & & & & & & & \\ \text { Urea } & & & & & & & \\ 56 & 22 & 48 & 60 & 47 & 77 & 26 & 47 \\ 112 & 28 & 44 & 38 & 43 & 70 & 28 & 42 \\ 168 & 18 & 36 & 29 & 46 & 56 & 20 & 34\end{array}$

Ammonium nitrate

$\begin{array}{rlllllll}56 & 50 & 71 & 70 & 61 & 52 & 31 & 56 \\ 112 & 38 & 58 & 49 & 48 & 62 & 32 & 48 \\ 168 & 21 & 53 & 30 & 55 & 57 & 21 & 40\end{array}$

Ammonium sulfate

$\begin{array}{rrrrr}56 & 37 & 65 & 72 & 58 \\ 112 & 39 & 50 & 47 & 45 \\ 168 & 34 & 47 & 42 & 41\end{array}$

Analysis of Variance

$\begin{array}{lcccccc}\text { N source } & 0.01 & 0.05 & 0.05 & \text { NS } & 0.05 & \text { NS } \\ \text { AN + AS vs U } & 0.01 & 0.05 & 0.05 & - & - & - \\ \text { AN vs AS } & \text { NS } & \text { NS } & \text { NS } & - & - & - \\ \text { N rate } & 0.05 & 0.05 & 0.01 & \text { NS } & \text { NS } & \text { NS } \\ \text { N linear } & 0.05 & 0.05 & 0.01 & \text { NS } & \text { NS } & \text { NS } \\ \text { N quadratic } & \text { NS } & \text { NS } & \text { NS } & \text { NS } & \text { NS } & \text { NS } \\ \text { N source X } & 0.05 & \text { NS } & \text { NS } & \text { NS } & 0.05 & \text { NS }\end{array}$

rate

${ }^{1} \mathrm{~N}$ rates in 1990 were 78,157 and $235 \mathrm{~kg} \mathrm{~N} \mathrm{ha}$.

tein concentration responses to $\left(\mathrm{NH}_{4}\right)_{2} \mathrm{SO}_{4}$ and $\mathrm{NH}_{4} \mathrm{NO}_{3}$ were similar each year. There appears to have been no benefit from the $\mathrm{SO}_{4}{ }^{2+}$ salt in increasing indiangrass or caucasian bluestem forage yield, crude protein concentration, or fertilizer $\mathrm{N}$ recovery at this site. Warm-season grasses display good tolerance to low soil $\mathrm{pH}$ and high exchangeable Al levels (Jung et al. 1988), and did not appear to be limited by these soil properties.

Although this study was not designed to compare the 2 grasses, some interesting differences stand out. Caucasian bluestem forage yields varied considerably with year, and may have been more dependent upon precipitation amounts and distribution during the growing season. Berg (1990) reported significant year-toyear variation in old world bluestem forage yield responses to $\mathrm{N}$ fertilizer due to wide variation in growing season precipitation in western Oklahoma. In our study, caucasian bluestem produced greater forage yields than indiangrass in 1987 with a single forage harvest, and in 1989 with 2 forage harvests. But indiangrass produced greater forage yields than caucasian bluestem in 1988 and 1990, even though caucasian bluestem was harvested twice. Indiangrass tended to have greater crude protein concentrations than caucasian bluestem from 1985-1987 when the forage was harvested on the same day. However, in 1988-1990, when the first caucasian bluestem harvest was taken earlier in the growing season to allow for a regrowth harvest, caucasian bluestem had greater crude protein concentrations.

Indiangrass yields increased with increasing $\mathrm{N}$ rates up to 168 $\mathrm{kg} \mathrm{N} \mathrm{Na}^{-1}$. In Iowa, Hall et al. (1982) reported that indiangrass generally responded positively to $\mathrm{N}$ through $75 \mathrm{~kg} \mathrm{~N} \mathrm{ha}^{-1}$, and often through $150 \mathrm{~kg} \mathrm{~N} \mathrm{ha*}$, and in Nebraska warm-season grasses responded to rates of up to $180 \mathrm{~kg} \mathrm{~N}^{\mathrm{N} a^{-1}}$ (Rehm et al. 1976).

Caucasian bluestem yields peaked at $101 \mathrm{~kg} \mathrm{~N} \mathrm{ha}^{-1}$ in 1985,132 $\mathrm{kg} \mathrm{N} \mathrm{ha}^{-1}$ in $1986,122 \mathrm{~kg} \mathrm{~N}^{-1}$ in $1987,129 \mathrm{~kg} \mathrm{~N}^{-1}$ in 1989 , and $161 \mathrm{~kg} \mathrm{~N} \mathrm{ha}^{-1}$ in 1990 . In this study, caucasian bluestem forage yields peaked at greater $\mathrm{N}$ rates than the $66 \mathrm{~kg} \mathrm{~N}$ ha.1 recommended for caucasian bluestem (Berg 1985) and the $70 \mathrm{~kg} \mathrm{~N} \mathrm{ha}^{-1}$ recommended for old world bluestem (Berg 1990) in northwestern Oklahoma. However, average growing season precipitation is over $20 \mathrm{~cm}$ greater in southwestern Missouri compared to northwestern Oklahoma, allowing greater responses to $\mathrm{N}$.

Our results suggest that for a single forage harvest, indiangrass would be preferred due to its better yield stability. However, under multiple harvests and for late summer forage production, caucasian bluestem would be better. Both grasses grew well on infertile soils of the Ozarks.

\section{Literature Cited}

Berg, W.A. 1985. Soil fertility practices for old world bluestems, p. 34-41. In: Proc. Conference on Old World Bluestems in the Southern Great Plains. Coop. Ext. Serv., Okla. State Univ., Stillwater, Okla.

Berg, W.A. 1990. Old world bluestem responses to nitrogen fertilization. J. Range Manage. 43:265-270.

Berg, W.A. 1993. Old world bluestem response to fire and nitrogen fertilizers. J. Range Manage. 46:421-425.

Black, C.C. 1971. Ecological implications of dividing plants into groups with distinct photosynthetic production capabilities. Adv. Ecol. Res. 7:87-114.

Bremner, J.M., and C.S. Mulvaney. 1982. Nitrogen-Total, p. 595-624. In: A.L. Page, R.H. Miller, and D.R. Keeney (eds.), Methods of soil analysis, part 2. Chemical and microbial properties. Amer. Soc. Agron., Soil Sci. Soc. Amer., Madison, Wisc.

Brown, R.H. 1978. A difference in $\mathrm{N}$ use efficiency in $\mathrm{C}_{3}$ and $\mathrm{C}_{4}$ plants and its implication in adaption and evolution. Crop Sci. 18:93-97.

Brown, R.H. 1985. Growth of $C_{3}$ and $C_{4}$ grasses under low $N$ levels. Crop Sci. 25:954-957.

Campbell, C.A., D.R. Cameron, W. Nicholaichuk, and H.R. Davidson. 1977. Effects of fertilizer $N$ and soil moisture on growth, $N$ content, and moisture use by spring wheat. Can. J. Soil Sci. 57:289310.

Caswell, E.T., and D.C. Godwin. 1984. The efficiency of nitrogen fertilizers applied to cereals in different climates, p. 1-55. In: P.B. Tinker and A. Lauchli (eds.), Advances in plant nutrition, Vol. 1. Praeger Scientific, New York.

Griffin, J.L., P.J. Wangsness, and G.A. Jung. 1980. Forage quality evaluation of two warm-season range grasses using laboratory and animal measurements. Agron. J. 72:951-956.

Hall, K.E., J.R. George, and R.R. Riedl. 1982. Herbage dry matter yields of switchgrass, big bluestem and indiangrass with $\mathrm{N}$ fertilization. Agron. J. 74:47-51.

Hargrove, W.L. 1988. Evaluation of ammonia volatilization in the field. J. Prod. Agr. 1:104-111.

Jackson, J.E., and G.W. Burton. 1962. Influence of sod treatment and nitrogen placement on the utilization of urea nitrogen by coastal bermudagrass. Agron. J. 54:47-49.

Jung, G.A., J.A. Shaffer, and W.L. Stout. 1988. Switchgrass and big bluestem responses to amendments on strongly acid soil. Agron. J. 80:669-676.

Jung, G.A., J.A. Shaffer, W.L. Stout, and M.T. Panciera. 1990. 
Warm-season grass diversity in yield, plant morphology, and nitrogen concentration and removal in Northeast USA. Agron. J. 82:21-26.

Mathews, B.W., and R.E. Joost. 1989. Use of sulfate salts to reduce subsoil aluminum toxicity: a review. J. Hawaiian Pac. Agr. 2:24-30.

McMurphy, W.E., C.E. Denman, and B.B. Tucker. 1975. Fertilization of native grasses and weeping lovegrass. Agron. J. 67:233-236.

Morris, R.J., R.H. Fox, and G.A. Jung. 1982. Growth, P uptake, and quality of warm and cool-season grasses on a low available $P$ soil. Agron. J. 74:125-129.

Perry, L.J., and D.D. Baltensperger. 1979. Leaf and stem yields and forage quality of three $\mathrm{N}$-fertilized warm-season grasses. Agron. J. 71:355-358.

Rehm, G.W., R.C. Sorensen, and W.J. 1976. Time and rate of fertilizer application for seeded warm-season and bluegrass pastures. I. Yield and botanical composition. Agron. J. 68:759-764.

Soil Conservation Service. 1993. Pasture Management Guide for the Ozarks. Southwest Missouri Resource Conservation and Development Council, Republic, Mo.

Staley, T.E., W.L. Stout, and G.A. Jung. 1991. Nitrogen use by tall fescue and switchgrass on acidic soils of varying water holding capacity. Agron. J. 83:732-738.
Steel, R.G.D, and J.H. Torrie. 1980. Principles and procedures of statistics. McGraw-Hill Book Co., N.Y.

Stout, W.L., G.A. Jung, J.A. Shaffer, and R. Estepp. 1986. Soil water conditions and yield of tall fescue, switchgrass, and caucasian bluestem in the Appalachian Northeast. J. Soil Water Conserv. 41:184186.

Waller, S.S., L.E. Moser, and P.E. Reece. 1985. Understanding grass growth: The key to profitable livestock production. Trabon Printing Co., Kansas City, Mo.

Westerman, R.L., R.J. O'Hanlon, G.L. Fox, and D.L. Minter, 1983. Nitrogen fertilizer efficiency in bermudagrass production. Soil Sci. Soc. Amer. J. 47:810-817.

Wilkinson, S.R., and G.W. Langdale. 1974. Fertility needs of warmseason grasses, p. 119-145. In: D.A. Mays (ed.), Forage fertilization. Amer. Soc. Agron., Crop Sci. Soc. Amer., and Soil Sci. Soc. Amer., Madison, Wisc.

Wuenscher, M.L., and G.C. Gerloff. 1971. Growth of Andropogon scoparius (little bluestem) in phosphorus deficient soils. New Phytol. 70:1035-1042 